\title{
Increasing biomass of winter wheat using sorghum biochars
}

\author{
Gilbert C. Sigua • Kenneth C. Stone • Patrick G. Hunt • \\ Keri B. Cantrell • Jeffrey M. Novak
}

Accepted: 9 September 2014 / Published online: 28 November 2014

(C) INRA and Springer-Verlag France 2014

\begin{abstract}
Biochar is a black solid formed by pyrolysis of biomass such as crop residues. Biochar could be used for soil fertilization, carbon sequestration, and improvement of soil structure. Here, we tested the effect of sorghum biochars on winter wheat, with or without supplemental inorganic phosphorus, in a greenhouse. The application rate for sorghum residues and sorghum biochars based on a yield goal of 200 bushels ha $^{-1}$ was $13 \mathrm{Mg} \mathrm{ha}^{-1}$. Inorganic phosphorus was added at the rate of $40 \mathrm{~kg} \mathrm{P} \mathrm{ha}{ }^{-1}$. Results show that addition of sorghum biochars increased the total biomass of winter wheat grown by about $31 \%$ over the control plants. Addition of supplemental inorganic phosphorus did not increase the total biomass. Our findings suggest that the pyrolitic transformation of sorghum residues into sorghum biochars is a better strategy for both environmental and crop productivity improvement in the Coastal Plains region.
\end{abstract}

Keywords Sorghum residues $\cdot$ Sorghum biochars $\cdot$ Winter wheat $\cdot$ Aboveground biomass $\cdot$ Belowground biomass . Ultisols · Coastal Plains

\section{Introduction}

Current concerns about rising global population growth combined with global food security necessitate major optimization in agricultural management. This will require preservation and replenishment of soil organic matter to sustain nutrient cycling, improve water- and nutrient-use efficiency, and mitigate

G. C. Sigua $(\bowtie) \cdot$ K. C. Stone $\cdot$ P. G. Hunt $\cdot$ K. B. Cantrell $\cdot$

J. M. Novak

Coastal Plains Soil, Water, and Plant Research Center, Agricultural

Research Service, United States Department of Agriculture, 2611

West Lucas St, Florence, SC 29501, USA

e-mail: gilbert.sigua@ars.usda.gov climate change (Jones et al. 2012). The fertility of highly weathered Ultisols in the southeastern Coastal Plains region of the USA is low. In this region, intensive crop production depletes soil nutrients and reduces soil organic carbon. Production and export of large amounts of biomass for bioenergy and grain production removes a substantial amount of mineral nutrients from soil (Sigua et al. 2004a, b). Repeated annual harvest of crop residues could reduce soil organic carbon levels (Sigua 2009). The application of organic residues such as sorghum and corn is critically needed for fertility maintenance of Ultisols as it leads to the formation of organic matter. Since the ancient times, farmers have recognized the importance of crop residues in enhancing crop yields. However, addition of crop residues may not always increase crop yields because of initial immobilization of nitrogen due to high inputs of carbon through crop residues. The mixed results from crop residue application studies are of importance for residue management practices. There is an increasing need to assess the true effects of crop residue application in enhancing agricultural crop yields.

Application of crop residues in agricultural systems is an important factor in the control of soil fertility and nutrient cycling. Other agronomic interventions would include addition of carbon-sequestering minerals to soil and addition of pyrolyzed organic residues (Lehmann 2007; Ambus and Jensen 1997; Jensen 1994). Pyrolysis of crop biomass generates a by-product called "biochar," which can be recycled to sustain nutrient and carbon concentrations in biomass production fields (Schnell et al. 2012; Lehmann 2007). The use of biochar as a soil amendment enhances soil fertility and offsets expenses for fertilizer and lime. An increase in soil fertility is the most frequently reported benefit linked to adding biochar to soils (Novak and Busscher 2012; Manya 2012; Busscher et al. 2010; Novak et al. 2009; Lehmann et al. 2006). Biochar has been described as a possible means to improve soil fertility and sequester carbon to mitigate climate change (Lehmann 
et al. 2006, 2011; Lehmann 2007). Additionally, Woolf et al. (2010) reported that production of biochar and its storage in soils might have had abated climate change by sequestering carbon while simultaneously providing energy and increasing crop yields.

Presently, the relationship between biochar properties and its potential to enhance biomass productivity is still unclear and does not always allow the establishment of appropriate process conditions to produce a biochar with desired characteristics (Novak and Busscher 2012; Manya 2012). Jones et al. (2012) claimed that the lack of biochar in agricultural policy affecting agricultural productivity as opposed to incorporation of crop residues is due to its potential negative impacts on soil quality. The other barrier to technology implementation has been the lack of commercial biochar available to farmers. With respect to both the positive and negative aspect of biochar on shortand long-term functioning of the agroecosystem, there are few studies that dealt with the utilization of raw crop residues (uncharred) versus pyrolyzed materials from the same feedstock source for plant biomass productivity (Novak and Watts 2013). Gaskin et al. (2010) reported that nitrogen from biochar might not be available to plants. Inconsistencies between reported effects of biochar derived from pyrolysis of crop biomass and those for other sources suggest that additional research is needed. The use of more stable compounds such as carbonized materials from incomplete combustion of organic materials such as black carbon, pyrogenic feedstocks, and charcoal could provide a long-term stability for maintaining high levels of soil organic matter and available nutrients in the soil (Glaser et al. 2002). On the other hand, applying organic amendments such as crop residues, biosolids, organic wastes, and manure has been shown to increase soil fertility and improve soil physical and chemical properties, but these usually mineralized rapidly (Busscher et al. 2011). The longevity of easily decomposable organic amendments like crop residues raises the spectre of their long-term contributions to soil carbon sequestration.

Although most soil properties were improved following application of crop residues and/or pyrolyzed crop residues, there is still a need to pursue additional research that will improve our understanding of the impact of soil fertility enhancement because the effect could vary greatly between uncharred sorghum residues and pyrolyzed sorghum residues. We hypothesized that sorghum biochars would deliver more positive effects on winter wheat biomass than sorghum residues. The objective of this study was to evaluate the effects of sorghum residues and sorghum biochars, with or without supplemental inorganic phosphorus fertilizer, on uptake and aboveground and belowground biomass of winter wheat grown in two Coastal Plains Ultisols.

\section{Materials and methods}

\subsection{Soil and site description}

Two soil types were used in this experiment: the Norfolk soil (fine loamy, kaolinitic, thermic, Typic Kandiudults) and Dunbar soil (fine, kaolinitic, thermic, Aeric Paleaquults). Both soils belong to the Ultisols Soil Order (US Soil Taxonomy) and formed in extensively weathered Coastal Plains marine sediments with the clay fraction dominated by kaolinite. The Norfolk is a well-drained soil located in upland landscape position, while the Dunbar is a poorly drained soil located in closed depressional areas (Daniels et al. 1999). Norfolk soils were collected from the Clemson University Pee Dee Research \& Education Center, Darlington, SC, with a long history (greater than 30 years) of row crop production. Dunbar soils were collected at the Coastal Plains Soil, Water, and Plant Research Center in Florence County, SC.

The Ap horizons of the Norfolk and Dunbar soils were collected using a front-end loader to remove the top $15 \mathrm{~cm}$ of soil. The soil samples were air-dried and then passed through a sieve with 2-mm openings to remove plant material and large aggregates. Table 1 shows some selected soil physical and chemical properties of the two soils used in the study.

\subsection{Feedstock description and biochar production}

Grain sorghum (Sorghum vulgaris L.) stovers were hand collected from a 7.7-ha field at the Coastal Plains Soil, Water, and Plant Research Center in Florence County, SC. The raw sorghum residues was hammer milled (PPH1000d; Pellet Pro, Davenport, IA) to approximately $6 \mathrm{~mm}$ particle size. The moisture content of milled sorghum was determined to be $40.7 \%(\mathrm{wt} / \mathrm{wt})$. Moisture content of the sorghum residues was further reduced to less than $17 \%$ (wt/wt) by spreading the residue thin $(2-8 \mathrm{~cm})$ and allowing it to undergo solar drying in the greenhouse.

Pyrolytic runs of the raw sorghum residues were performed at $500{ }^{\circ} \mathrm{C}$. Prior to a run, the sorghum was oven-dried $\left(103{ }^{\circ} \mathrm{C}\right)$ overnight and then loaded into a mesh basket and placed into a Lindberg electric box furnace equipped with a gas tight retort (Model 51662; Lindberg/MPH, Riverside, MI). This particular furnace-retort was specially modified with a stochastic state-space regulator (Cantrell and Martin 2012) to ensure precision regulation of the final charring temperature. Samples were pyrolyzed under the following temperature schedule: (1) $60 \mathrm{~min}$ at $200{ }^{\circ} \mathrm{C}$ for equilibration, (2) $240 \mathrm{~min}$ at $500{ }^{\circ} \mathrm{C}$, and (3) cooldown $4.25{ }^{\circ} \mathrm{C} \mathrm{min}{ }^{-1}$ to $100{ }^{\circ} \mathrm{C}$. During the initial $200{ }^{\circ} \mathrm{C}$ hold, the retort was purged using industrial-grade nitrogen gas flowing at $15 \mathrm{~L} \mathrm{~min}^{-1}$; the nitrogen gas flow for the remaining operation was reduced to $1 \mathrm{~L} \mathrm{~min}^{-1}$ (equivalent to 0.6 and 0.04 retort chamber exchanges per minute, respectively) to maintain anoxic conditions. After charring, 
Table 1 Selected soil chemical and mineralogical properties of the two soils and selected chemical properties of sorghum residues and sorghum biochars that were used in the study

\begin{tabular}{|c|c|c|}
\hline Soil properties & Dunbar soil & Norfolk soil \\
\hline \multicolumn{3}{|l|}{ Physical } \\
\hline Sand $\left(\mathrm{g} \mathrm{kg}^{-1}\right)$ & 674 & 807 \\
\hline Silt $\left(\mathrm{g} \mathrm{kg}^{-1}\right)$ & 257 & 167 \\
\hline Clay $\left(\mathrm{g} \mathrm{kg}^{-1}\right)$ & 69 & 26 \\
\hline Soil texture & Sandy loam & Loamy sand \\
\hline \multicolumn{3}{|l|}{ Chemical } \\
\hline $\mathrm{pH}$ & 5.5 & 5.9 \\
\hline $\mathrm{C}\left(\mathrm{g} \mathrm{kg}^{-1}\right)$ & 13.8 & 5.8 \\
\hline $\mathrm{N}\left(\mathrm{g} \mathrm{kg}^{-1}\right)$ & 0.12 & 0.82 \\
\hline $\mathrm{P}\left(\mathrm{mg} \mathrm{kg}^{-1}\right)$ & 95.4 & 20.3 \\
\hline $\mathrm{K}\left(\mathrm{mg} \mathrm{kg}^{-1}\right)$ & 168.3 & 121.5 \\
\hline $\mathrm{Ca}\left(\mathrm{mg} \mathrm{kg}^{-1}\right)$ & 419.4 & 244.5 \\
\hline $\operatorname{Mg}\left(\mathrm{mg} \mathrm{kg}^{-1}\right)$ & 113.2 & 54.7 \\
\hline $\mathrm{Na}\left(\mathrm{mg} \mathrm{kg}^{-1}\right)$ & 34.8 & 29.6 \\
\hline $\mathrm{Al}\left(\mathrm{mg} \mathrm{kg}^{-1}\right)$ & 270.6 & 83.0 \\
\hline $\mathrm{Fe}\left(\mathrm{mg} \mathrm{kg}^{-1}\right)$ & 23.6 & 10.7 \\
\hline $\mathrm{Cu}\left(\mathrm{mg} \mathrm{kg}^{-1}\right)$ & 0.19 & 0.18 \\
\hline $\mathrm{Zn}\left(\mathrm{mg} \mathrm{kg}^{-1}\right)$ & 3.5 & 3.8 \\
\hline Properties & Sorghum residues & Sorghum biochars \\
\hline $\mathrm{C}\left(\mathrm{g} \mathrm{kg}^{-1}\right)$ & 800.0 & 750.5 \\
\hline $\mathrm{N}\left(\mathrm{g} \mathrm{kg}^{-1}\right)$ & 9.9 & 13.0 \\
\hline $\mathrm{P}\left(\mathrm{g} \mathrm{kg}^{-1}\right)$ & 1.1 & 3.5 \\
\hline $\mathrm{K}\left(\mathrm{g} \mathrm{kg}^{-1}\right)$ & 24.2 & 66.9 \\
\hline $\mathrm{Ca}\left(\mathrm{g} \mathrm{kg}^{-1}\right)$ & 2.6 & 8.5 \\
\hline $\operatorname{Mg}\left(\mathrm{g} \mathrm{kg}^{-1}\right)$ & 2.0 & 6.2 \\
\hline $\mathrm{S}\left(\mathrm{g} \mathrm{kg}^{-1}\right)$ & 1.4 & 2.2 \\
\hline $\mathrm{Na}\left(\mathrm{mg} \mathrm{kg}^{-1}\right)$ & 26.0 & 146.0 \\
\hline $\mathrm{Fe}\left(\mathrm{mg} \mathrm{kg}^{-1}\right)$ & 75.0 & 217.0 \\
\hline $\mathrm{Cu}\left(\mathrm{mg} \mathrm{kg}^{-1}\right)$ & 5.0 & 11.0 \\
\hline $\mathrm{Zn}\left(\mathrm{mg} \mathrm{kg}^{-1}\right)$ & 25.0 & 75.0 \\
\hline
\end{tabular}

the samples remained in an inert atmosphere, but they were allowed to cool overnight to less than $60{ }^{\circ} \mathrm{C}$ for subsequent removal from the retort. Following this charring procedure, the sorghum biochar recovery was about $37.2 \pm 2.7 \%$ (on dry weight basis). Selected chemical properties of uncharred and pyrolyzed sorghum that were used in the study are presented in Table 1.

\subsection{Experimental design and experimental setup}

Experimental treatments consisting of sorghum residues with phosphorus, sorghum residues without phosphorus, sorghum biochars with phosphorus, and sorghum biochars without phosphorus and the control were replicated four times using a $2 \times 5$ split plot arrangement in completely randomized block design. Soil types were the main treatment effect, while sorghum residues or sorghum biochar with or without phosphorus was the sub-treatment effect. The total number of pots used in the study was 80 . Half of the total pots had $6.1 \mathrm{~kg}$ of Norfolk soil, and the remaining half of the pots had the same amount of Dunbar soils. Each pot received blanket applications of $125 \mathrm{~kg} \mathrm{~N} \mathrm{ha}^{-1}$ and $50 \mathrm{~kg} \mathrm{~K} \mathrm{ha}^{-1}$ before planting. The application rate for sorghum residues and sorghum biochars based on a yield goal of 200 bushels ha ${ }^{-1}$ was $13 \mathrm{Mg} \mathrm{ha}^{-1}$. The required amount of inorganic phosphorus added to each pot was $40 \mathrm{~kg} \mathrm{ha}^{-1}$. All the required amounts of the fertilizer treatments were all mixed together for $30 \mathrm{~min}$ with Norfolk soil and Dunbar soil, respectively, using a barrel roller.

Each pot was planted with 24 wheat seeds (Pioneer, variety: 26R20) following the two rows in crossing pattern $\left(12\right.$ seeds row $\left.^{-1}\right)$. Each pot received about $0.32 \mathrm{~cm}$ of irrigation water per day using an automatic sprinkler system for the first 3 days and gradually increased to about $0.64 \mathrm{~cm}$ after 5 days and further increased to about $1.1 \mathrm{~cm}$ of irrigation water per day thereafter. Half of the required amount of irrigation water is being delivered in the morning ( $9 \mathrm{AM}$ ), and the remaining half amount is being delivered in the afternoon (2 PM). Fungicide treatments $\left(\right.$ Tebustar $^{\circledR}$ ) at the rate of $0.3 \mathrm{~L} \mathrm{ha}^{-1}$ were sprayed on day 50. An additional amount of inorganic $\mathrm{N}$ $\left(28 \mathrm{~kg} \mathrm{ha}^{-1}\right)$ was added on day 57.

\subsection{Harvesting of aboveground and belowground biomass}

Plants were harvested by cutting the aboveground biomass from the surface of the soil. Freshly cut aboveground biomass was oven-dried at $60^{\circ} \mathrm{C}$ for about $48 \mathrm{~h}$. Belowground biomass was separated from the soil by soaking the entire pot in a bucket of water followed by several washings to remove the soil from the roots (Fig. 1). The belowground biomass was also oven-dried at $60{ }^{\circ} \mathrm{C}$ for about $48 \mathrm{~h}$, making sure that plant tissues were completely dried. Both the aboveground and belowground biomass were weighed and prepared for tissue analyses (P, K, Ca, Mg, $\mathrm{Cu}, \mathrm{Fe}, \mathrm{Al}$, and $\mathrm{Mo}$ ) as described below.

\subsection{Tissue analyses of aboveground and belowground biomass}

Both the aboveground and belowground biomass were ground to pass through a 1-mm mesh screen in a Wiley mill. Ground samples were digested in an auto-block using a mixture of nitric and perchloric acid and were analyzed for tissue $\mathrm{P}, \mathrm{K}, \mathrm{Ca}, \mathrm{Mg}, \mathrm{Cu}, \mathrm{Fe}, \mathrm{Al}$, and $\mathrm{Mo}$ concentrations using inductively coupled plasma (ICP) spectroscopy. Nutrient uptake (aboveground and belowground) of winter wheat was calculated using the equation below. 

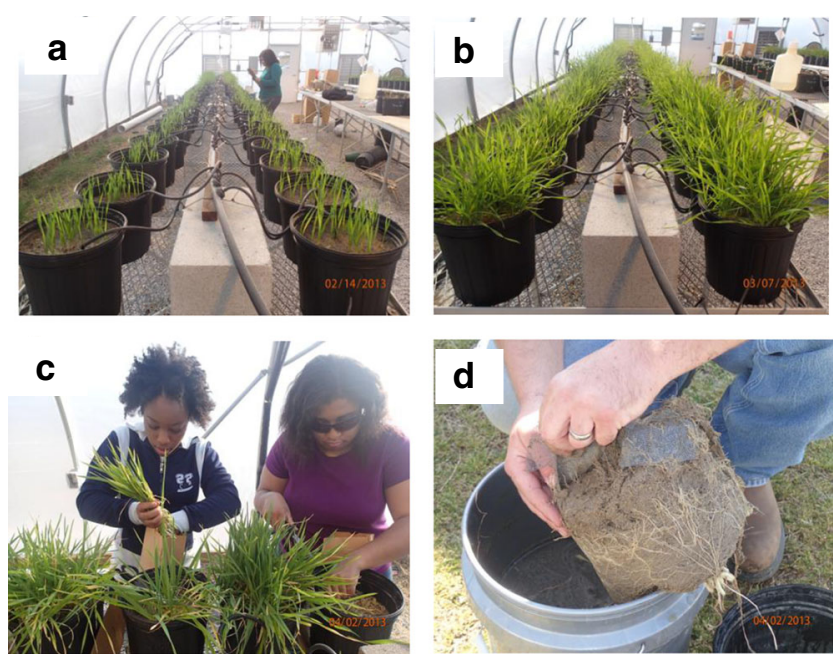

Fig. 1 Harvesting of aboveground and belowground biomass of winter wheat: (1) early growth stand (shown in $\mathbf{a}$ and b) of winter wheat, (2) harvesting of biomass by cutting the aboveground biomass from the surface of the soil (shown in c), and (3) separating belowground biomass from soil by soaking the entire pot in a bucket of water (shown in d)

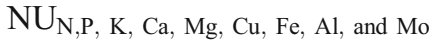

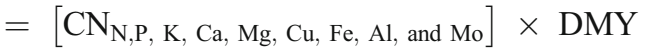

where $\mathrm{NU}=$ nutrient uptake $\left(\mathrm{kg} \mathrm{ha}^{-1}\right), \mathrm{CN}=$ concentration of nutrients $\left(\mathrm{g} \mathrm{kg}^{-1}\right)$, and DMY $=$ dry matter yield $\left(\mathrm{kg} \mathrm{ha}^{-1}\right)$.

\subsection{Statistical analysis}

Data were analyzed by following the principles of a two-way ANOVA using PROC GLM. The model included soil types (Norfolk vs. Dunbar) and sources of nutrients (sorghum residues vs. sorghum biochars). For this study, an $F$ test indicated a significant $(p \leq 0.05)$ effect of soil types, so means of sorghum treatments - sorghum residues with phosphorus, sorghum residues without phosphorus, sorghum biochars with phosphorus, and sorghum biochars without phosphorus effects - were separated following the procedures of least significant differences (LSD) test, using appropriate mean squares (SAS Institute 2000).

\section{Results and discussion}

3.1 Plant total biomass (aboveground and belowground biomass)

While total biomass (aboveground+belowground) of winter wheat varied significantly with sorghum treatments $(p \leq 0.001)$ and soil type $(p \leq 0.05)$, the interaction effects between sorghum treatments and soil type did not significantly influence the total biomass of winter wheat (Table 2 and Fig. 2). The overall total biomass (averaged across sorghum treatments) of winter wheat grown in pots with Dunbar sandy loam was higher than the total biomass of winter wheat in pots with Norfolk loamy sand (Table 2). Averaged across soil types, the greatest total biomass of $61.1 \pm 15.5$ was from plants treated with sorghum biochars (Fig. 3).

Addition of sorghum biochars with or without phosphorus increased total biomass of winter wheat by about $31 \%$ over the control plants. The resulting total biomass of winter wheat from the additions of sorghum residues with phosphorus (39.1 $\pm 17.2 \mathrm{~g} \mathrm{pot}^{-1}$ ) and sorghum residues without phosphorus $\left(38.9 \pm 16.4 \mathrm{~g} \mathrm{pot}^{-1}\right)$ was statistically comparable with the total biomass from the control plants $\left(46.5 \pm 6.2 \mathrm{~g} \mathrm{pot}^{-1}\right)$. The average decrease in the total biomass for winter wheat treated with sorghum residues with phosphorus and sorghum residues without phosphorus was about $19 \%$ when compared with the control and $56 \%$ when compared with plants treated with sorghum biochars with phosphorus and sorghum biochars without phosphorus. Addition of supplemental inorganic phosphorus to both sorghum residues and sorghum biochars did not increase the total biomass of winter wheat when averaged across soil types (Fig. 3).

The two greatest aboveground biomass in our study were observed from winter wheat fertilized with sorghum biochars without phosphorus and sorghum biochars with phosphorus, while the least aboveground biomass were from plants that were fertilized with sorghum residues without phosphorus and sorghum residues with phosphorus. These values have demonstrated that the aboveground biomass of wheat plants with sorghum residues decreased by about $43 \%$ relative to the average total biomass of winter wheat that were treated with sorghum biochars with or without inorganic phosphorus. The least amount of belowground biomass $\left(20.9 \pm 4.2 \mathrm{~g} \mathrm{pot}^{-1}\right)$ was from the control plants (Fig. 2). Belowground biomass of plants that were fertilized with sorghum biochars was significantly higher than the belowground biomass of the control plants, but not significantly different from winter wheat that was treated with sorghum biochars with phosphorus and sorghum residues with phosphorus and sorghum residues without phosphorus (Fig. 2). Results have shown greater beneficial effects of sorghum biochars than sorghum residues on aboveground and belowground biomass of winter wheat.

We had hypothesized prior to starting the study that sorghum biochars would favorably affect biomass and uptake of winter wheat. Our results have supported our hypothesis. Addition of sorghum biochars enhanced the biomass and uptake of winter wheat. Biomass and uptake responses of winter wheat have demonstrated widely differing agronomic effects between sorghum residues and sorghum biochars. Our results have suggested that sorghum biochars are more likely to influence the biomass and uptake of wheat, and both effects could be long lasting. It has been observed in several studies 


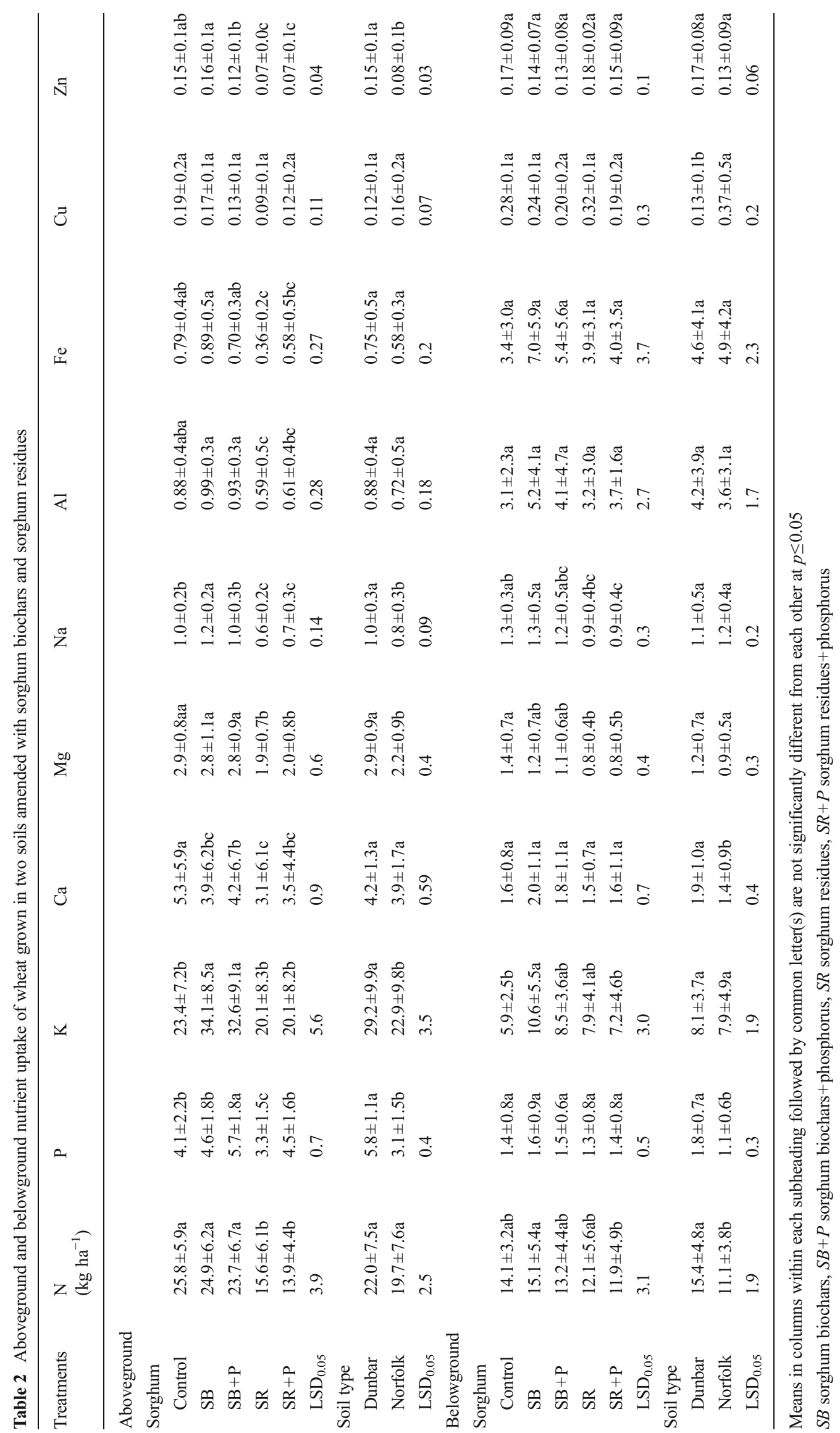


Fig. 2 Aboveground (blue bars) and belowground (red bars) biomass of winter wheat (averaged across Dunbar and Norfolk soils) as affected by the different sorghum treatments. Means of aboveground and belowground biomass of winter wheat are significantly different $(p \leq 0.05)$ when letters located at the top of each bar are different
BIOMASS (g pot $\left.{ }^{-1}\right)$

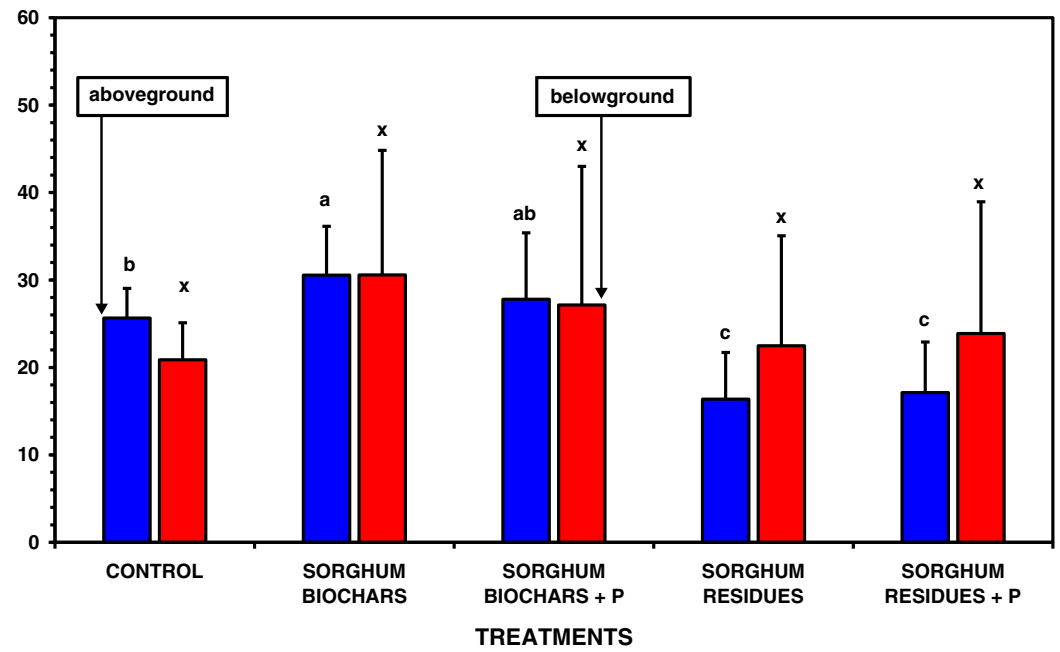

that biochar additions improve soil fertility and thus increased crop yields (Chan et al. 2007). Little is known about turnover times and decomposition rates of biochars in soils, and longterm storage function contradicts the fertility function of biochars. Biochar amendments have previously been known to increase crop productivity by improving the physical and biochemical properties of cultivated soils.

While the greatest total biomass of 61.1 and $54.9 \mathrm{~g} \mathrm{pot}^{-1}$ in our study was from plants treated with sorghum biochars without phosphorus and sorghum biochars with phosphorus, respectively, the resulting total biomass of winter wheat from the additions of sorghum residues with phosphorus and sorghum residues without phosphorus was statistically comparable and even lower than the total biomass of the control plants. A number of factors could have had affected the outcome of our study. For instance, differences in the rapidity and stability between sorghum residues and sorghum biochars oxidized in the soil depend on the physical and chemical composition, especially the sorghum biochars, along with the physical and chemical conditions of the surrounding soil environment. In addition, the $\mathrm{C}: \mathrm{N}$ ratio of the biochars, age of the feedstocks, and the degree of disintegration or particle size of the biochars can govern the amount of their nutrients released in soil (Novak and Busscher 2012). The value of biochar application for soil improvement and enhancing crop productivity in Norfolk and Dunbar soils seems promising and is probably related to the huge surface area of sorghum biochars and the micropores for beneficial microorganism microhabitat and increasing soil organic carbon contents. Undoubtedly, the rate of decomposition of biochars is governed by the size of the particle subject to microbial attack. Our results have shown that additions of sorghum biochar have resulted in greater biomass productivity of
Fig. 3 Total biomass of winter wheat (averaged across Dunbar and Norfolk soils) as affected by the different sorghum treatments. Means of total biomass of winter wheat are significantly different $(p \leq 0.05)$ when letters located at the top of each bar are different
TOTAL BIOMASS

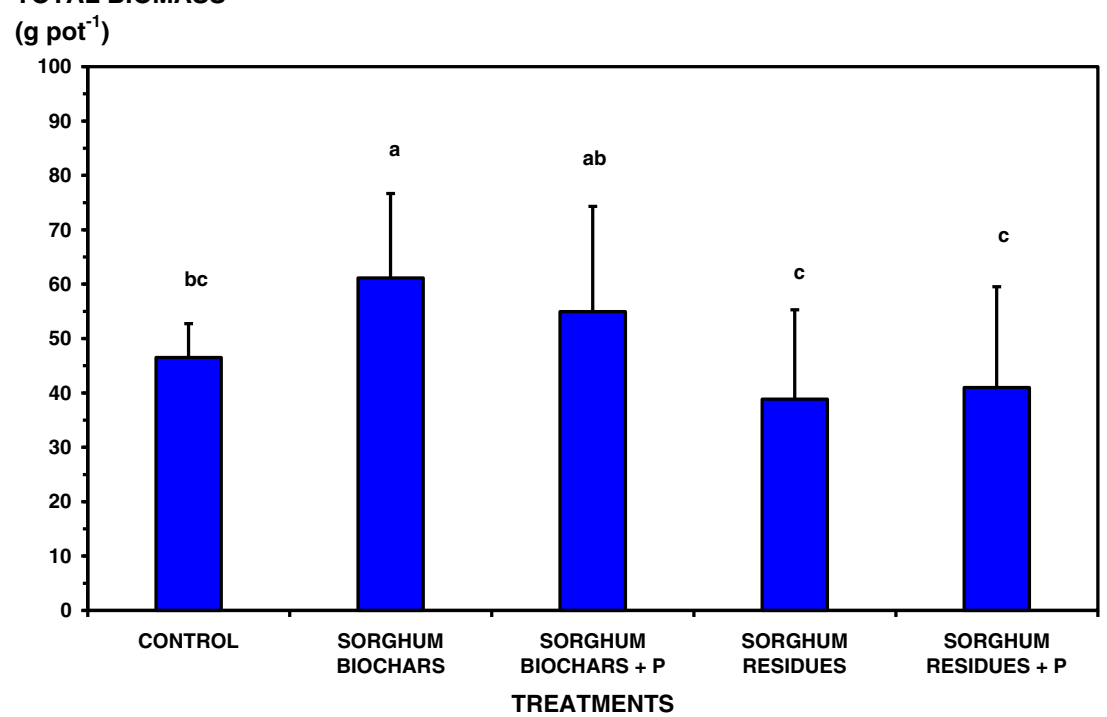


winter wheat compared with sorghum residues. As a rule, the small particulate materials are more readily degraded than are the large particles (Sims and Frederick 1970). Earlier results of studies have shown that large charcoal particles originated from forest wildfires remained in soils for a thousand years (Pessenda et al. 2001; Gavin et al. 2003). Smaller particles derived from grassland burning can hardly be detected in steppe ecosystems (Forbes et al. 2006).

Another aspect of seeing a significant reduction in total biomass of wheat from the addition of sorghum residues when compared to plants treated with sorghum biochars could be related to the mineralization-immobilization turnover ratio of nitrogen in the soil. According to the hypothesis of mineralization-immobilization turnover in the soil, incorporation of crop residues like the sorghum residues in the soil causes a rapid increase in the microbial biomass on and around the residue particles and the soil microbial biomass will act both as a sink for nutrients and a catalyst for decomposition (Gilmour et al. 1985). Immediately after adding a carbon substrate to the soil, the energy and growth substrates generated by heterotrophic metabolism will increase microbial biomass and hence the nitrogen demand of decomposer populations. The decomposition rate of organic materials added to soil is generally most rapid during the first weeks (Gilmour et al. 1985; Sorensen 1981). Everything else being equal, materials added to the soil with a $\mathrm{C}: \mathrm{N}$ ratio greater than $24: 1$ will result in a temporary nitrogen deficit and those with a $\mathrm{C}: \mathrm{N}$ ratio less than 24:1 will result in a temporary nitrogen surplus. Since the average $\mathrm{C}: \mathrm{N}$ ratio of the sorghum residues $(\sim 44.48: 1)$ in our study is greater than $24: 1$, this may have had resulted in a nitrogen deficit. The resulting nitrogen deficit following incorporation of sorghum residues could have had a negative influence on the growth and yield of winter wheat.

Noticeably, the total biomass of winter wheat varied widely with soil type. The overall total biomass of winter wheat grown in Dunbar soil was significantly greater than the total biomass of winter wheat grown in Norfolk soil. The overall difference in total biomass between these two soils was about $6.9 \mathrm{~g} \mathrm{pot}^{-1}$. The differences in soil profile development between Dunbar and Norfolk soils may have had caused some of the impacts on winter wheat's total biomass. For instance, differences in the soil organic carbon and total nitrogen and clay contents between Dunbar and Norfolk soils are due to differences in soil formation (Daniels et al. 1999) and may have had affected the results of our study. Both the sorghum residues and sorghum biochars may be more stable in a poorly drained organic matter-enriched sandy soil such as the Dunbar series than in well-drained sandy soils with inherently lower soil organic carbon and total nitrogen contents such as the Norfolk series. The rate of sorghum residue decomposition is influenced by soil biological and chemical properties, temperature, and the nature and chemical composition of the plant residues.

\subsection{Nutrient uptake (aboveground and belowground)}

Table 2 shows the average nutrient uptake of winter wheat's aboveground and belowground biomass. Overall, the nutrient uptake in wheat's aboveground and belowground biomass varied widely between soil types $(p \leq 0.001)$ and among sorghum treatments $(p \leq 0.001)$. Aboveground nitrogen uptake of winter wheat treated with sorghum biochars without phosphorus $\left(24.9 \pm 6.2 \mathrm{~kg} \mathrm{ha}^{-1}\right)$ and sorghum biochars with phosphorus $\left(23.7 \pm 5.7 \mathrm{~kg} \mathrm{ha}^{-1}\right)$ were comparable to the nitrogen uptake of wheat in the control pots $\left(25.8 \pm 4.1 \mathrm{~kg} \mathrm{ha}^{-1}\right)$. These values, however, were significantly different from the nitrogen uptake of wheat with sorghum residues without phosphorus and sorghum residues with phosphorus. Sorghum residues may have had a negative effect on aboveground nitrogen uptake of wheat because the average nitrogen uptake of wheat treated with sorghum residues without phosphorus and sorghum residues with phosphorus was about 40 and $46 \%$ lower than the average nitrogen uptake of winter wheat in the control pots (Table 2).

Belowground uptake of nitrogen varied widely with sorghum treatments $(p \leq 0.001)$ and soil type $(p \leq 0.001)$. The greatest nitrogen uptake was from plants treated with sorghum biochars without phosphorus, and the lowest nitrogen uptake was from plants fertilized with sorghum residues with phosphorus (Table 2). Nitrogen uptake of winter wheat treated with sorghum residues (with or without phosphorus) was statistically comparable to the nitrogen uptake of wheat in the control pots. Again, belowground nitrogen uptake of wheat could be negatively affected by sorghum residues. Belowground nitrogen uptake of wheat in Dunbar soil was about $28 \%$ more when compared to the nitrogen uptake of wheat grown in Norfolk soil (Table 2).

The overall nitrogen uptake of winter wheat in our study for Dunbar soils was about $22.0 \pm 7.5$ and $19.7 \pm 7.6 \mathrm{~kg} \mathrm{ha}^{-1}$ for Norfolk soils. The lower nutrient uptake of winter wheat grown in soils with sorghum residues could be associated with the foregoing discussion on net immobilizationmineralization of nutrients from the two sources of sorghum residues. Again, our results supported our hypothesis that nutrient uptake responses of winter wheat have demonstrated widely differing agronomic effects between sorghum residues and sorghum biochars. Our results agree with the findings of Rao and Mikkelsen (1976), who reported limitation of plant growth and low tissue nitrogen level due to nitrogen immobilization with straw application. Nitrogen immobilization reduces the amount of mineral nitrogen that is available to plants which exerts an adverse effect on plant growth and yield. 
Phosphorus uptake (aboveground and belowground) of winter wheat was not affected by the different sorghum treatments, but varied widely with soil type $(p \leq 0.001)$. The aboveground phosphorus uptake of wheat in Dunbar soil was $5.8 \pm$ $1.1 \mathrm{~kg} \mathrm{ha}^{-1}$ compared with $3.1 \pm 1.5 \mathrm{~kg} \mathrm{ha}^{-1}$ phosphorus uptake of wheat in Norfolk soil. Belowground phosphorus uptake was smaller in magnitude compared with the aboveground uptake of wheat. Dunbar soil had a phosphorus uptake of $1.8 \pm 0.7 \mathrm{~kg} \mathrm{ha}^{-1}$ and Norfolk soil had $1.1 \pm 0.6 \mathrm{~kg} \mathrm{P} \mathrm{ha}^{-1}$ (Table 2).

Aboveground potassium uptake of wheat fertilized with sorghum residues without phosphorus $\left(20.1 \pm 8.3 \mathrm{~kg} \mathrm{ha}^{-1}\right)$ and sorghum residues with phosphorus $\left(20.1 \pm 8.2 \mathrm{~kg} \mathrm{ha}^{-1}\right)$ were statistically $(p \leq 0.05)$ comparable with the control plants $\left(23.4 \pm 7.2 \mathrm{~kg} \mathrm{ha}^{-1}\right)$. Potassium uptake of wheat that were treated with sorghum biochars without phosphorus and sorghum biochars with phosphorus were considerably higher when compared with plants treated with sorghum residues and the control plants (Table 2). These results again demonstrate the favorable effect of sorghum biochars in augmenting potassium uptake of wheat. Aboveground potassium uptake was also affected by soil type $(p \leq 0.001)$. The average potassium uptake of winter wheat grown in Dunbar soil was about $29.2 \pm 9.9 \mathrm{~kg} \mathrm{ha}^{-1}$ compared with $22.9 \pm 9.8 \mathrm{~kg} \mathrm{ha}^{-1}$ for wheat grown in Norfolk soil (Table 2). Winter wheat treated with sorghum biochars without phosphorus had the greatest belowground potassium uptake followed by plants treated with sorghum biochars with phosphorus, sorghum residues without phosphorus, sorghum residues with phosphorus, and the control. Belowground potassium uptake of winter wheat grown in Dunbar soil $\left(8.1 \pm 3.7 \mathrm{~kg} \mathrm{ha}^{-1}\right)$ was not different from potas-

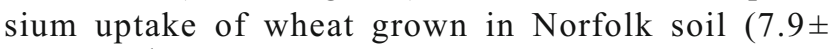
$4.9 \mathrm{~kg} \mathrm{ha}^{-1}$ ).

Aboveground calcium uptake of wheat varied significantly with the different sorghum treatments $(p \leq 0.001)$, but not with soil type (Table 2). On the other hand, belowground calcium uptake of wheat was not significantly affected by sorghum treatments, but varied widely between soil types $(p \leq 0.001)$. The aboveground calcium uptake $\left(\mathrm{kg} \mathrm{ha}^{-1}\right)$ in descending order is as follows: control, sorghum biochars with phosphorus, sorghum biochars without phosphorus, sorghum residues with phosphorus, and sorghum residues without phosphorus. The average belowground calcium uptake of wheat grown in Dunbar soil was about $1.9 \pm 1.0 \mathrm{~kg} \mathrm{ha}^{-1}$ compared with the calcium uptake of wheat grown in Norfolk soil (1.4 \pm $1.0 \mathrm{~kg} \mathrm{ha}^{-1}$ ). Belowground calcium uptake in Norfolk soil was not affected by sorghum treatments (Table 2).

Aboveground magnesium uptake of wheat treated with sorghum biochars without phosphorus and sorghum biochars with phosphorus were comparable to the magnesium uptake of the control plants. These values, however, were significantly higher than the magnesium uptake of wheat fertilized with sorghum residues without phosphorus $\left(1.9 \pm 0.7 \mathrm{~kg} \mathrm{ha}^{-1}\right)$ and sorghum residues with phosphorus $\left(2.0 \pm 1.8 \mathrm{~kg} \mathrm{ha}^{-1}\right)$. The average aboveground magnesium uptake of plants grown in Dunbar soil was about $2.9 \pm 0.9 \mathrm{~kg} \mathrm{ha}^{-1}$, while magnesium uptake of wheat in Norfolk soil was about $2.2 \pm 0.9 \mathrm{~kg} \mathrm{ha}^{-1}$ (Table 2). The belowground magnesium uptake $\left(\mathrm{kg} \mathrm{ha}^{-1}\right)$ of winter wheat in descending order is as follows: control, sorghum biochars without phosphorus, sorghum biochars with phosphorus, sorghum residues without phosphorus, and sorghum residues with phosphorus.

Winter wheat treated with sorghum biochars with phosphorus had the greatest aboveground uptake for sodium, while the lowest sodium uptake was from plants treated with sorghum residues without phosphorus. Aboveground sodium uptake of wheat with sorghum biochars with phosphorus was $1.0 \pm$ $0.3 \mathrm{~kg} \mathrm{ha}^{-1}$, while aboveground sodium uptake of wheat treated with sorghum residues with phosphorus was $0.7 \pm$ $0.3 \mathrm{~kg} \mathrm{ha}^{-1}$ (Table 2). Winter wheat grown in Dunbar soil $\left(1.0 \pm 0.3 \mathrm{~kg} \mathrm{ha}^{-1}\right)$ had higher sodium uptake than winter wheat grown in Norfolk soil $\left(0.8 \pm 0.3 \mathrm{~kg} \mathrm{ha}^{-1}\right)$. The belowground sodium uptake $\left(\mathrm{kg} \mathrm{ha}^{-1}\right)$ of winter wheat in descending order is as follows: sorghum biochars without phosphorus, control, sorghum biochars with phosphorus, sorghum residues without phosphorus, and sorghum residues with phosphorus.

Belowground uptake of wheat for aluminum, iron, copper, and zinc was not affected by the different sorghum treatments, but results vary significantly with soil type $(p \leq 0.001)$. On the other hand, the aboveground aluminum, iron, and zinc uptake were significantly affected by the different sorghum treatments ( $p \leq 0.001)$, but were not affected by soil type (Table 2 ). The greatest aboveground aluminum, iron, and zinc uptake were all observed from plants treated with sorghum biochars without phosphorus, while the lowest aboveground uptake for aluminum, iron, and zinc were all observed from plants treated with sorghum residues without phosphorus (Table 2).

Particle size of the sorghum treatments could have had contributed to the overall results involving nutrient uptake of winter wheat grown in two Coastal Plains Ultisols. The sorghum residues definitely had much coarser size ranging from 2 to $5 \mathrm{~mm}$ compared to the average size of $<2 \mathrm{~mm}$ for the sorghum biochars. Particle size of sorghum residues may have had a pronounced effect on residue decomposition and the mineralization-immobilization turnover in the soil. It has been suggested that small particles may decompose faster than larger particles (Jensen 1994). The much finer particles of the sorghum biochars compared with the particle size of sorghum residues will have larger surface area and greater dispersion in soil, and these would increase the susceptibility to microbial attack, especially if residues are not readily penetrated by fungi and bacteria (Amato et al. 1984). The microbial biomass and products formed during the initial decomposition of sorghum residues will be more susceptible to immobilization of nitrogen, phosphorus, potassium, sodium, aluminum, iron, and zinc. On the other hand, the 
microbial biomass and products formed during the initial decomposition of sorghum biochars may be better protected against further decomposition due to more intimate mixing of the substrates and the mineral soils (Jensen 1994; Stickler and Frederick 1959). Since sorghum biochars are being protected from further decomposition, we can expect to have a longer and steady source of nitrogen, phosphorus, potassium, sodium, aluminum, iron, and zinc in the soil over time.

The potential net immobilization of nutrients from larger particles of sorghum residues and the potential net mineralization of nitrogen and other nutrients (phosphorus, potassium, sodium, aluminum, iron, and zinc) in the soil may have had explained the greater total biomass of wheat treated with sorghum biochars. Greater winter wheat biomass in soils treated with sorghum biochars may have also increased nutrient uptake of winter wheat. The rapidity and stability with which given uncharred sorghum residues and/or sorghum biochars are oxidized in the soil will depend on the physical and chemical composition of plant residues and the physical and chemical conditions of the surrounding soil environment. It is possible that the decomposing sorghum biochars may have had stimulated the mineralization of soil organic nitrogen because of greater total biomass and nutrient uptake of winter wheat than winter wheat fertilized with uncharred sorghum biochar. Results of our study were supported by the work of Jansson and Persson (1982) who reported that the outcome of the mineralization-immobilization process and the stabilization of residue in soil organic matter pools after incorporation of the residues in the soil would affect the availability of phosphorus, potassium, sodium, aluminum, iron, and zinc to succeeding crops.

\section{Conclusion}

Our results fully support our hypothesis that sorghum biochars would deliver a more positive effect on the biomass of winter wheat than the sorghum residues. In highly weathered Coastal Plains Ultisols, addition of pyrolyzed sorghum biochars has improved soil fertility and carbon sequestration and has no negative consequences in terms of wheat biomass and uptake. Our results may seem to indicate that the pyrolytic transformation of sorghum residue into sorghum biochar is a better strategy for both environmental and crop productivity improvement. Results have shown greater efficacy of sorghum biochars than sorghum residues on biomass and uptake of winter wheat. Addition of sorghum biochars increased total biomass of winter wheat by about $31 \%$ over the control plants. Our study has provided important information on the contrasting effects of sorghum residues and sorghum biochars in terms of satisfying the long-term environmental risk assessment and better understanding for the use of uncharred and pyrolyzed crop residues in agriculture. Addition of supplemental inorganic phosphorus to both the pyrolyzed and sorghum residues did not increase the total biomass of winter wheat. The results from our greenhouse study demonstrate that the beneficial agronomic benefits of sorghum biochars and sorghum residues have to be verified for different soil types and crops under field conditions. Since one biochar type will not resolve all productivity issues in all soils because of differences in its quality and its interaction with soil particles and soil microbes, there is a need to conduct additional research on the efficacy of different biochars in improving crop productivity in soils with depleted soil fertility like most Ultisols in Coastal Plains.

Acknowledgments We are extending our gratitude and appreciation to William Brigman, Paul Shumaker, Jerry Martin, and Katie Lewis for their greenhouse and laboratory assistance.

Disclaimer Mention of a specific product or vendor does not constitute a guarantee or warranty of the product by the USDA or imply its approval to the exclusion of other products by the USDA or imply its approval to the exclusion of other products that may be suitable.

\section{References}

Amato M, Jackson B, Butler JH, Ladd JN (1984) Decomposition of plant material in Australian soils. II. Residual organic ${ }^{14} \mathrm{C}$ and ${ }^{15} \mathrm{~N}$ from legume plant parts decomposing under field and laboratory conditions. Australian Jour Soil Res 22:331-341. doi:10.1071/ SR9840331

Ambus P, Jensen ES (1997) Nitrogen mineralization and denitrification as influenced by crop residue particle size. Plant Soil 197:261-270. doi:10.1023/A:1004276631914

Busscher WJ, Novak JM, Evans DE, Watts DW, Niandou MAS, Ahmedna M (2010) Influence of pecan biochar on physical properties of a Norfolk loamy sand. Soil Sci 175:10-14. doi:10.1097/ss. 0b013e3181cb7f46

Busscher WJ, Novak JM, Ahmenda M (2011) Physical effects of organic matter amendment of southeastern US coastal loamy sand. Soil Sci 176:661-667. doi:10.1097/ss.0b013e3182357ca9

Cantrell KB, Martin JH (2012) Stochastic state-space temperature regulations of biochar production. J Sci Food Agric 92:481-489. doi:10. 1002/jsfa.4618

Chan KY, Van Zwieten L, Meszaros I, Downie A, Joseph S (2007) Agronomic values of greenwaste biochar as a soil amendment. Aust J of Soil Res 45:629-634. doi:10.1071/SR07109

Daniels RB. Buol SW. Kleiss HJ. Ditzler CA (1999) Soil systems of North Carolina. North Carolina State University Technical Bulletin 314, North Carolina State University, Raleigh, NC.

Forbes MS, Raison RJ, Skejemstad JO (2006) Formation, transformation and transport of black carbon (charcoal) in terrestrial and aquatic ecosystem. Sci Total Environ 370:190-205. doi:10.1016/j.scitotenv. 2006.06.007

Gaskin JW, Speir RA, Harris KC, Das RD, Morris LA, Fisher DS (2010) Effect of peanut hull and pine chip biochar on soil nutrients, corn nutrient status, and yield. Agron J 102:1096-1106. doi:10.2134/ agronj2009.0083 
Gavin DG, Brubaker LB, Lertzman KP (2003) Holocene fire history of a coastal temperature rain forest based on soil charcoal radiocarbon dates. Ecology 84:186-201

Gilmour JT, Clark MD, Sigua GC (1985) Estimating net nitrogen mineralization from carbon dioxide evolution. Soil Sci Soc Am J 49: 1398-1402. doi:10.2136/sssaj1985.03615990049000060013×

Glaser B, Lehmann J, Zech W (2002) Ameliorating physical and chemical properties of highly weathered soils in the tropics with charcoal—a review. Biol Fertil Soils 35:219-230. doi:10.1007/S00374002-0466-4

Institute SAS (2000) SAS/STAT user's guide, Release 6.03. SAS Institute. Cary, $\mathrm{NC}$

Jansson SL. Persson J (1982) Mineralization and immobilization of nitrogen. In Nitrogen in agricultural soils (Stevenson, FJ, ed), pp. 229-252. American Society of Agronomy, Madison. WI

Jensen ES (1994) Mineralization-immobilization of nitrogen in soil amended with low C:N ratio plant residues with different particle sizes. Soil Biol Biochem 26:519-521. doi:10.1016/0038-0717/ BF01420218

Jones DL, Rousk J, Edwards-Jones G, DeLuca TH, Murphy DV (2012) Biochar-mediated changes in soil quality and plant growth in a three year field trial. Soil Biol Biochem 45:113-124. doi:10.1016/j. soilbio.2011.10.012

Lehmann JM (2007) A handful of carbon. Nature 447:143-144. doi:10. $1038 / 447143 a$

Lehmann JM, Gaunt J, Rondon M (2006) Bio-char sequestration in terrestrial ecosystems - a review. Mitig Adapt Strateg Glob Chang 11:395-419. doi:10.1007/S11027-005-9006-5

Lehmann JM, Rillig M, Thies J, Masiello CA, Hockaday WC, Crowley D (2011) Biochar effects on soil biota: a review. Soil Biol Biochem 43: 1812-1836. doi:10.1016/j.soilbio.2011.04.022

Manya JJ (2012) Pyrolysis for biochar purposes: a review to establish current knowledge gaps and research needs. Environ Sci Technol 46:7939-7954. doi:10.1021/es30102g

Novak JM, Busscher WJ (2012) Selection and use of designer biochars to improve characteristics of southeastern USA Coastal Plain degraded soil. In: Lee JW (ed) Advanced biofuels and bioproducts. Springer, New York, pp 69-96

Novak JM, Watts DW (2013) Augmenting soil water storage using uncharred switchgrass and pyrolysed biochars. Soil Use Manage 29:98-104. doi:10.1111/sum. 12026
Novak JM, Busscher WJ, Laird DA, Ahmenda D, Watts DW, Niandou MAS (2009) Impact of biochar on fertility of a southeastern Coastal Plain soil. Soil Sci 174:105-112

Pessenda LCR, Gouveja SEM, Aravena R (2001) Radiocarbon dating of total soil organic matter and humin fraction and its composition with $\mathrm{C}-14$ ages of fossil charcoal. Radiocarbon 43: 595-601

Rao DN, Mikkelsen D (1976) Effects of rice straw incorporation on rice plant growth and nutrition. Agron 68:752-755. doi:10.2134/ agronj1976.00021962006800005001×

Schnell RW, Vietor DM, Provin TL, Munster CL, Capareda S (2012) Capacity of biochar application to maintain energy crop productivity: soil chemistry, sorghum growth and runoff water quality effects. J Environ Qual 41:1044-1051. doi:10.2134/ jeq2011.0077

Sigua GC (2009) Recycling biosolids and lake-dredged materials to pasture-based animal agriculture: alternative nutrient sources for forage productivity and sustainability. Agron Sustain Dev J 29(1): 143-160. doi:10.1051/agro:2008037

Sigua GC, Holtkamp ML, Coleman SW (2004a) Assessing the efficacy of dredged materials from lake Panasoffkee, Florida: implication to environment and agriculture. Part 1: Soil and environmental quality aspect. ESPR- Environ Sci Pollut Res 11(5):321-326. doi:10.1007/ BF02979646

Sigua GC, Holtkamp ML, Coleman SW (2004b) Assessing the efficacy of dredged materials from lake Panasoffkee, Florida: implication to environment and agriculture. Part 2: Pasture establishment and forage quality. ESPR- Environ Sci Pollut Res 11(6):394-399. doi: 10.1007/BF02979659

Sims JL, Frederick LR (1970) Nitrogen immobilization and decomposition of corn residue in soils and sand as affected by residue particle size. Soil Sci 109:355-361

Sorensen LH (1981) Carbon-nitrogen relationships during the humification of cellulose in soil containing different amounts of clay. Soil Biol Biochem 13:313-321. doi:10.1016/0038-0717(81)90068-7

Stickler FC, Frederick LR (1959) Residue particle size as a factor in nitrate release from legume tops and roots. Agron J 51:271-274. doi:10.2134/agronj1959.00021962005100050007×

Woolf D, Amonette JE, Street-Perrot FA, Lehmann J, Joseph S (2010) Sustainable biochar to mitigate global climate change. Nat Commun 56:1-9 